\title{
An Optimal Design of the Inlet and Outlet Obstacles at USBR II Stilling Basin
}

\author{
Saba Soori \\ Department of Civil \\ Engineering, Azad University, \\ Central Tehran branch, \\ Tehran, Iran
}

\author{
Hamidreza Babaali \\ Department of Civil \\ Engineering, Azad University, \\ Khorramabad branch, \\ Lorestan, Iran \\ Khorramabad, Lorestan
}

\author{
Nasim Soori \\ Department of Civil \\ Engineering, Tabriz University, \\ Tabriz, Iran
}

\begin{abstract}
Hydraulic jump is one of the rapidly varied flows that different elements can be employed to control it in stilling basins. The purpose of this study is optimal design of obstacles at USBR II stilling basin of Nazloochay dam model. For this purpose, the obstacles at the end chute with thicknesses and heights of 0.5, 1, 1.5 and $2 \mathrm{~m}$ and 2, 3 and 4 steps at the end USBR II stilling basin have been considered. Then for the most optimal state, the pressure, water surface profile, turbulent kinetic energy, and turbulent kinetic energy dissipation investigated for discharging $830 \mathrm{~m}^{3} / \mathrm{s}$ by using K- $\varepsilon$ and RNG turbulence model and VOF method. According to changes in water height, obstacles selected with heights of 1 and 1.5 equal of standard state at the end chute and 3 steps at the end stilling basin. The comparison of numerical and experimental values of water surface and pressure profiles showed that numerical model has good agreement with experimental results. Also, hydraulic jump on adverse steps at the end stilling basin increase energy dissipation and stability of hydraulic jump. In addition, numerical model can be used to model stilling basins and measuring non-measurable parameters in laboratory.
\end{abstract}

Keywords: Optimal USBR II Stilling Basin, Chute Blocks, Adverse Steps, Numerical Model.

\section{INTRODUCTION}

Stilling basins are usually built at the downstream of structures such as chutes and gates to control the energy dissipation of hydraulic jump (Vischer and Hager, 1998; Chanson, 2015; Chow, 1959, Hamedi et al. 2016, 2014, 2012, 2011). In the energy dissipater structures, baffle blocks and end sills are used to prevent the existing jump and placing it in stilling basin, even if the tail water depth is less than the conjugate depth of free hydraulic jump (Peterka, 1984). Forester and Skrinde (1950) were the first ones who done studies about hydraulic jump on the adverse-sloped surface.

For the first time in Nimrod dam in 1975, a stilling basin was used with end steps where the basin was located in downstream of an ogee spillway, and the flow was controlled through 7 slide gates. The performance of stilling basin has been satisfied in terms of energy dissipation and eroding downstream (Hager, 1992). (Harleman, 1955) was one of the first researchers who investigated the role of baffle blocks and its effects on flow characteristics at stilling basins. (Armenio et al., 2000) studied the pressure fluctuations using a negative step at the end of hydraulic jump. Ohtsu and Yasuda (1991) investigated the hydraulic jump on adverse steps with the effect of tail water depth, Froude number and the step heights on the type of hydraulic jump and divided the hydraulic jump to six categories. In this regard, (Mossa et al., 2003) studied various types of hydraulic jump on the adverse step with a wider range of effective parameters. They proposed 11 graphs according to Froude number and tail water depth, and they divided the jump to 5 groups. Abdelazim and Yaser (2010) studied the effect of stilling basin shapes on submerged hydraulic jump. The results showed that stilling basins with end steps create the shortest submerged hydraulic jump in stilling basin. Zhao and Misra (2004) simulated hydraulic jump in 2-Dimentioal state and presented the results by velocity and water level profiles, calculating the amount of kinetic energy $(\mathrm{k})$ and energy loss ( $(\varepsilon)$. (Tiwari, 2013) designed a stilling basin model with the effect of wall and the end still and concluded that by a suitable design of the walls size, not only the efficiency of the stilling basin model increases, but also basin lengths decreases $29 \%$ in comparison to USBR IV stilling basin. Bharat and Tiwari (2014) studied several models of the stilling basin at the pipe outlet with rectangular and circular sections. They used studies of previous researcher's. Youngkyu et al. (2015) and Hamedi \& Fuentes (2016) experimentally studied hydraulic jump, energy dissipation, and characteristics of downstream flow for different types of spillways with sluice gate. Palermo and Pagliara (2015) compared two configurations of stilling basins and predicted the energy dissipation in downstream of the stilling basin for them. (Neveen, 2016) investigated the impact of channel slope on the characteristics of hydraulic jump and tested the attributes hydraulic jump in the vertical valves located in the downstream of a rectangular channel. (Gamal et al., 2016) explored the impact of different shapes of stilling basin with different heights of the end steps on characteristics of submerged hydraulic jump and energy dissipation in the downstream of a sluice gate. (Feimster, 2016) studied the impact of tail water on the designing several stilling basins in the USA.

Numerical methods have been used by various researchers in recent decades (Hamedi et al. 2016, Ketabdar 2016, Ketabdar and Hamedi 2016, Nik and Vahidi 2015) Mathematical models (Kamyab 2017a, b) exactly express issues when modeling some the hydraulic phenomena (Blocken and Gualtieri, 2012; Murzyn and Chanson, 2009a). Moreover, modeling can caused save of time and expense in comparison to the experimental work. (Chen et al., 2010) 3-Dimensionally simulated flow in stilling basins using VOF RNG $k-\varepsilon$ and Mixture RNG k- $\varepsilon$ turbulence models. The result showed that the calculated the parameters of water depth, velocity profile and distribution pressure are in good agreement with the 
experimental data, and the Mixture turbulence model is better than the VOF turbulence model to calculate the air entrainment. (Morovati et al., 2016 and Hamedi and Ketabdar 2016 explored energy dissipation in pooled stepped by using numerical simulation. in this studies, velocity distribution, energy dissipation, turbulent kinetic energy have been investigated in stepped spillway. (Guven et al., 2006) used neural network to predict pressure fluctuations in a sloped stilling basin and presented a formula to calculate average pressure fluctuations on based on the features with the most impact on the hydraulic jump. (Mojtahedi et al., 2015) investigated energy dissipation in stepped spillways by using physical modeling and numerical simulation. They used to an image processing method to obtained water surface profile. (Babaali et al., 2015)simulated hydraulic jump in converged stilling basin by using flow-3D. (Valero et al., 2016) numerically studied the performance of USBR III stilling basin at the downstream of the smooth and stepped spillways. They employed unsteady RANS equations, VOF method and RNG- k- $\varepsilon$ models to modelling free surface and turbulence. (Arnau et al., 2016) evaluated the performance of Flow-3D and OpenFOAM in the numerical modeling of hydraulic jump at a low Reynolds number.

In this study, the optimal performance of the USBR II stilling basin has been assessment with changing the structure of inlet and outlet obstacles at the stilling basin. Then, the flow was simulated by using Flow-3D software in stilling basin. Afterward, the thickness and height of the end blocks of chute changed, and the steps added to the end of USBR II stilling basin of Nazloochay dam model. Finally, the most optimal state of stilling basin selected.

\section{MATERIALS AND METHODS \\ 2.1 Experimental Model}

Nazloochay reservoir dam is an earth dam with a clay core and $100 \mathrm{~m}$ height which has been constructed on Nazloochay river in northwestern Urmia-Iran. The hydraulic model of the flooding discharge system was built based on similarity of the dimensionless Froude number with a scale of 1:40. The material of bottom, the walls of the spillway and stilling basin model is Plexiglas. USBR II stilling basin has been designed for 1000 year old floods for discharging $500 \mathrm{~m}^{3} / \mathrm{s}$.

To measure the discharge over a rectangular weir and to regulate the water level, the sluice gates were placed in the end channel at the downstream. The rectangular weir and sluice gate is used at the end of channel in downstream to measurement the discharge and regulation of water level. The flooding discharge system of dam includes input channel, free-ogee spillway, chutes and the USBR II stilling basin. USBRII stilling basin, with dimensions of $42 * 30 \mathrm{~m}$, has energy dissipater blocks at start and end of stilling basin. In Figure 1 the hydraulic model of Nazloochay dam is shown (Water Research Institute, 2000).

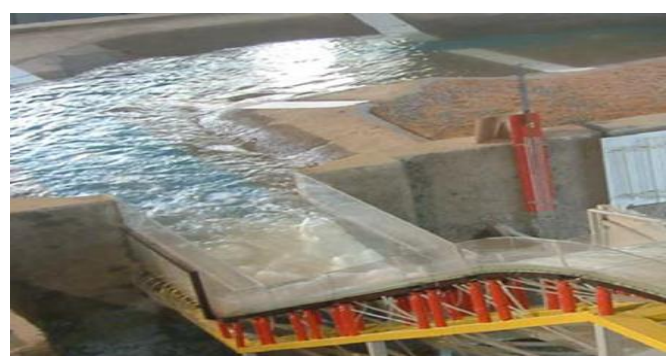

Figure 1. Hydraulic model of Nazloochay dam, Iran

\subsection{Numerical Modeling}

Although the flow pattern in stilling basins is very complex, the Navier-Stokes equations can presented a mathematically description about them. Nowadays, 3D numerical simulation of free surface flows has become a beneficial and commodious method (Wang and et al., 2009; Wu and Zheng, 2010).

In this study, Flow-3D software is used to simulate the flow in the stilling basin. This software solved governing equations by the finite volume method and is employed Fractional Area / Volume Obstacle Representation (FAVOR) and the Volume of Fluid (VOF) methods respectively to accuracy in modeling the rigid bodies and to simulate the fluid behavior. The Flow3D software defines the equations of continuity; momentum and the free surface profile as following:

\section{Continuity Equation}

$V_{F} \frac{\partial \rho}{\partial t}+\frac{\partial\left(\rho \rho u_{x}\right)}{\partial x}+R \frac{\partial\left(\rho \rho v_{Y}\right)}{\partial y}+\frac{\partial\left(\rho \rho w_{z}\right)}{\partial z}+\xi \frac{\rho u A_{x}}{x}=$

$R_{D I F}+R_{S O R}$

In Eq. (1) $V_{F}$ is the fractional volume of the fluid, $\rho$ is the fluid density, $(u, v, w)$ are the velocity components, $\left(A_{x}, A_{y}\right.$, $\left.A_{z}\right)$ are the fractional areas in $(x, y, z)$ directions, $R_{D I F}$ represents the diffusion caused by turbulence and $R_{S O R}$ is a mass source term.

\section{Momentum Equation}

$$
\begin{aligned}
& \frac{\partial \mathrm{u}}{\partial \mathrm{t}}+\frac{1}{V_{\mathrm{F}}}\left\{\mathrm{uA}_{\mathrm{x}} \frac{\partial \mathrm{u}}{\partial \mathrm{x}}+\mathrm{vA}_{\mathrm{y}} \mathrm{R} \frac{\partial \mathrm{u}}{\partial \mathrm{y}}+\mathrm{wA}_{\mathrm{z}} \frac{\partial \mathrm{u}}{\partial \mathrm{z}}\right\}-\xi \frac{\mathrm{A}_{\mathrm{y} u v}}{\mathrm{x} \mathrm{V}_{\mathrm{F}}}= \\
& -\frac{1}{\rho} \mathrm{R} \frac{\partial \mathrm{P}}{\partial \mathrm{x}}+\mathrm{G}_{\mathrm{X}}+\mathrm{f}_{\mathrm{X}}-\mathrm{b}_{\mathrm{X}}-\frac{\mathrm{R}_{\mathrm{SOR}}}{\rho \mathrm{V}_{\mathrm{F}}} \mathrm{u} \\
& \frac{\partial \mathrm{v}}{\partial \mathrm{t}}+\frac{1}{\mathrm{~V}_{\mathrm{F}}}\left\{\mathrm{uA}_{\mathrm{x}} \frac{\partial \mathrm{v}}{\partial \mathrm{x}}+\mathrm{v} \mathrm{A}_{\mathrm{y}} \mathrm{R} \frac{\partial \mathrm{v}}{\partial \mathrm{y}}+\mathrm{wA}_{\mathrm{z}} \frac{\partial \mathrm{v}}{\partial \mathrm{z}}\right\}+\xi \frac{\mathrm{A}_{\mathrm{y}} \mathrm{uv}}{\mathrm{x} \mathrm{V}_{\mathrm{F}}}= \\
& -\frac{1}{\rho} \mathrm{R} \frac{\partial \mathrm{P}}{\partial \mathrm{y}}+\mathrm{G}_{\mathrm{y}}+\mathrm{f}_{\mathrm{y}}-\mathrm{b}_{\mathrm{y}}-\frac{\mathrm{R}_{\mathrm{SOR}}}{\rho \mathrm{V}_{\mathrm{F}}} \mathrm{v} \\
& \frac{\partial \mathrm{w}}{\partial \mathrm{t}}+\frac{1}{\mathrm{~V}_{\mathrm{F}}}\left\{\mathrm{uA}_{\mathrm{X}} \frac{\partial \mathrm{w}}{\partial \mathrm{x}}+\mathrm{vA}_{\mathrm{y}} \mathrm{R} \frac{\partial \mathrm{w}}{\partial \mathrm{y}}+\mathrm{wA}_{\mathrm{z}} \frac{\partial \mathrm{w}}{\partial \mathrm{z}}\right\}= \\
& -\frac{1}{\rho} \frac{\partial \mathrm{P}}{\partial \mathrm{z}}+\mathrm{G}_{\mathrm{Z}}+\mathrm{f}_{\mathrm{Z}}-\mathrm{b}_{\mathrm{Z}}-\frac{\mathrm{R}_{\mathrm{SOR}}}{\rho \mathrm{V}_{\mathrm{F}}} \mathrm{w}
\end{aligned}
$$

In Momentum Eq. (2) $\left(G_{x}, G_{y}, G_{z}\right)$ are the components of acceleration of the body fluids, $\left(f_{x}, f_{y}, f_{z}\right)$ are the acceleration caused by viscosity and $\left(b_{x}, b_{y}, b_{z}\right)$ are the flow drop in porous media.

\section{Free Surface Profile}

Free surface profile is estimated by the function of the volume of fluid (VOF), i.e., $F(x, y, z)$. This function indicates the amount of fluid volume in the computational cell as Eq. (3):

$$
\frac{\partial F}{\partial t}+\frac{1}{V_{F}}\left\{\frac{\partial}{\partial x}\left(F A_{x} u\right)+\frac{\partial}{\partial y}\left(F A_{y} v\right)+\frac{\partial}{\partial z}\left(F A_{z} w\right)\right\}=0
$$


In Eq. (3), $F$ is between $[0,1]$ that $F=1$ indicates exiting fluid, and $F=0$ presents no fluid. In addition, $A$ is the average of flow area, and $(u, v, w)$ are the average velocities in the directions of $(x, y, z)$ respectively [Flow-3D Manual].

\subsection{VERIFICATION OF NUMERICAL MODEL}

In this study according to Figure 2, USBR II stilling basin has been modeled using Flow-3D software to verify the numerical model. To simulate a flow in USBR II stilling basin, the



number of meshes are $300 * 60 * 48$ in $(\mathrm{X}, \mathrm{Y}, \mathrm{Z})$ directions as non-uniform structured meshes.

The water surface and velocity has been considered for the upstream boundary condition and tail water elevation for downstream boundary condition. Also in this study, air entrainment model has been used due to air entrainment into flow in hydraulic jump and effect on energy dissipation in stilling basin.
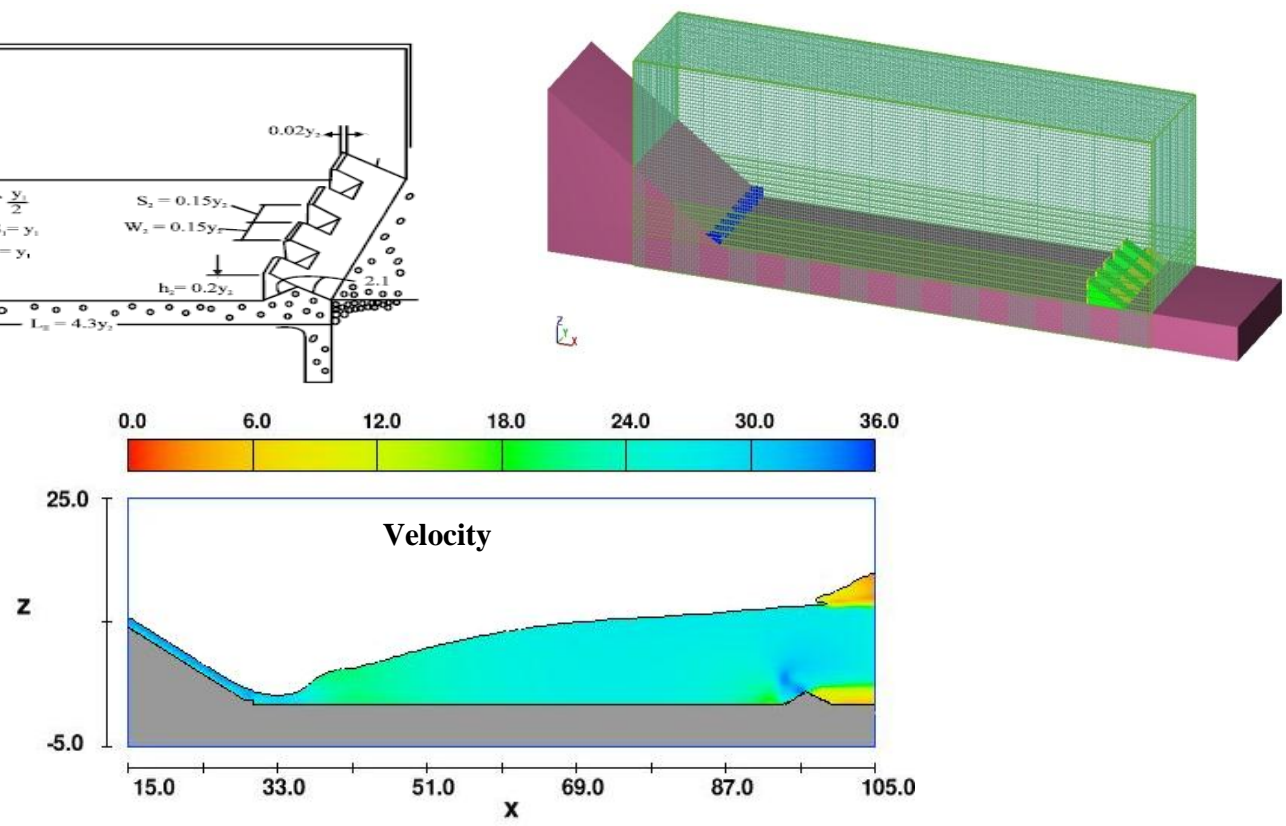

Figure 2. Numerical Simulation of USBR II stilling basin
In Table 1 the characteristics of the numerical and experimental model of USBR II stilling basin have been presented.

Table 1. Characteristics of models in USBR II stilling basin

\begin{tabular}{c|c|c}
\hline Models & $\begin{array}{c}\text { Experimental } \\
\text { Model }\end{array}$ & $\begin{array}{c}\text { Numerical } \\
\text { Model }\end{array}$ \\
\hline Basin length $(\mathrm{m})$ & 70.20 & \\
\hline Basin weight $(\mathrm{m})$ & 20 & \\
\hline Mesh Number & & $300 * 60 * 48$ \\
\hline Initial depth $(\mathrm{m})$ & 1.33 & 1.32 \\
\hline Conjugate depth $(\mathrm{m})$ & 16.38 & 15.92 \\
\hline Initial velocity $(\mathrm{m} / \mathrm{s})$ & 32.46 & 32.36 \\
\hline $\mathrm{q}\left(\mathrm{m}^{2} / \mathrm{s}\right)$ & 43.2 & 43.2 \\
\hline
\end{tabular}

Comparison of numerical and experimental values of water height in USBR II stilling basin in Figure 3 illustrate that the water height in numerical model has not difference with experimental model in the start of stilling basin, but $0.46 \mathrm{~m}$ difference has at the outlet of stilling basin (about less than $3 \%$ ). Therefore, result demonstrates a very high accuracy of the numerical modeling.

\section{RESULTS AND DISCUSSION}

In the hydraulic model of Nazloochay dam, hydraulic jump is created for discharges more than the design discharge at the outlet of the stilling basin, and flow affected on tail water waterway and river. In order to reach to a better performance and placing the hydraulic jump into the stilling basin for discharges higher than the design discharge, a strategy is making changes in the structures of the energy-dissipater blocks at the end of chute and putting dentate at the outlet of stilling basin. These changes are implemented as follows:

\subsection{Changes in Structures of stilling basin}

\subsubsection{Chute Blocks}

In the primary design of USBR II stilling basin, the thickness and height of energy dissipater blocks were considered to be $0.5 \mathrm{~m}$ at the end chute. In this study, the chute blocks were investigated with the thicknesses and heights of $0.5,1,1.5$ and 2 meters. In Figure 4, energy dissipater blocks are shown at the end chute in the USBR II stilling basin of Nazloochay dam model.

\subsubsection{End Structures of Stilling Basin}

In USBR II stilling basin, energy dissipater blocks are dentate designed at the end stilling basin. High rate of discharge lead to the erosion of dentate at the end of stilling basin and scour at the downstream waterways. Thus, by eliminating the dentate and creating adverse-sloped surface $(3: 1 ; \mathrm{H}: \mathrm{V})$ at the end of the stilling basin, the stilling basin acts like a ski jump bucket at high velocities (Figure 5), although a stable hydraulic jump is created into the stilling basin. 


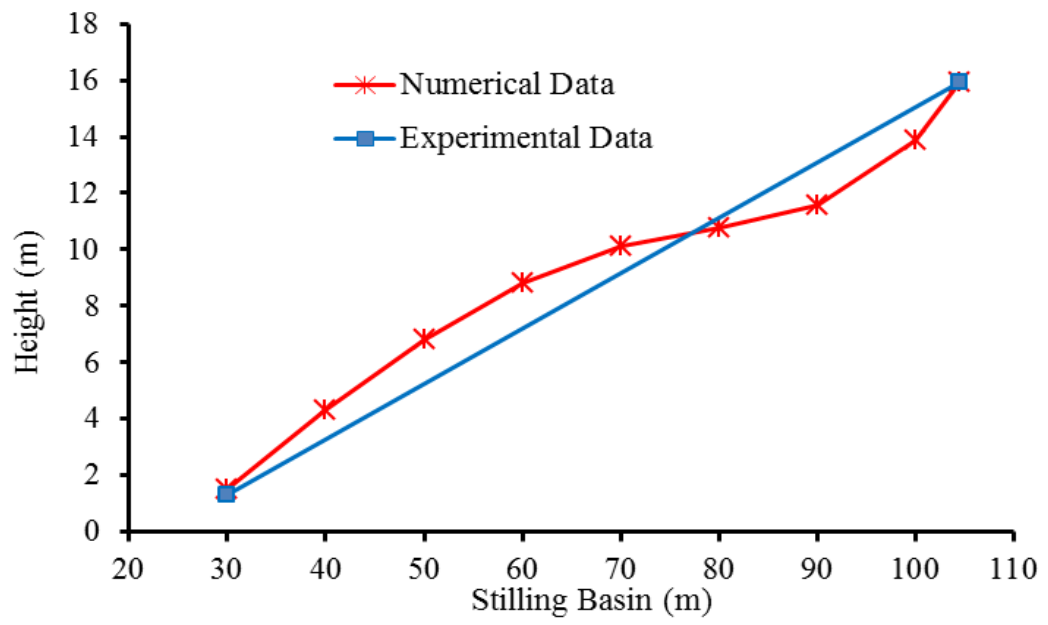

Figure 3. Water height at the length of stilling basin
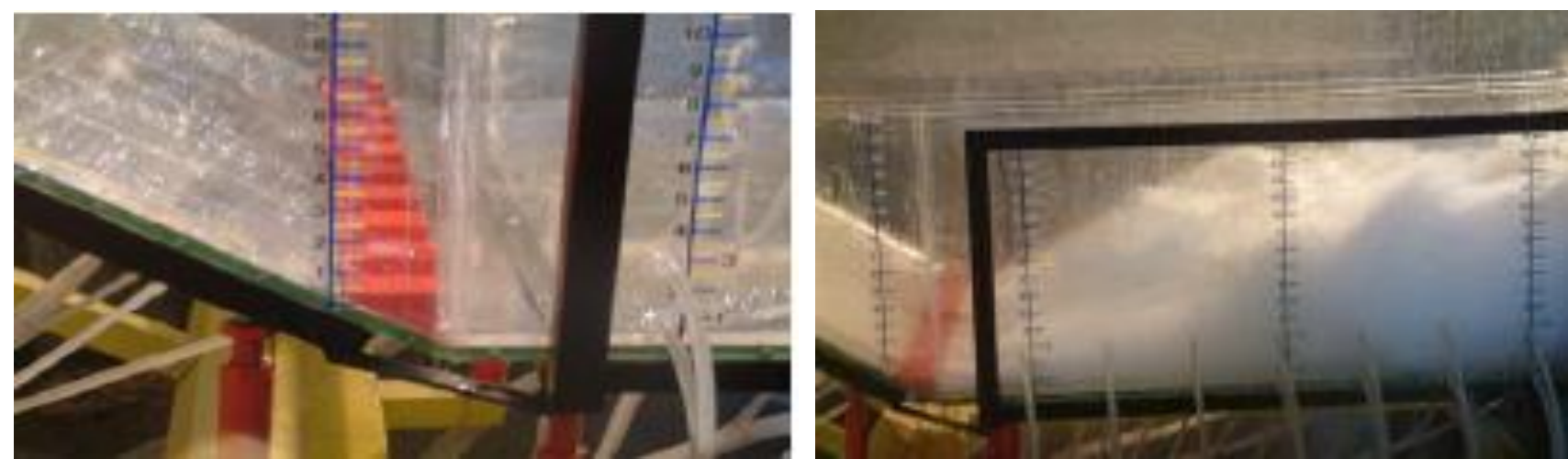

Figure 4. Chute Blocks at USBR II stilling basin

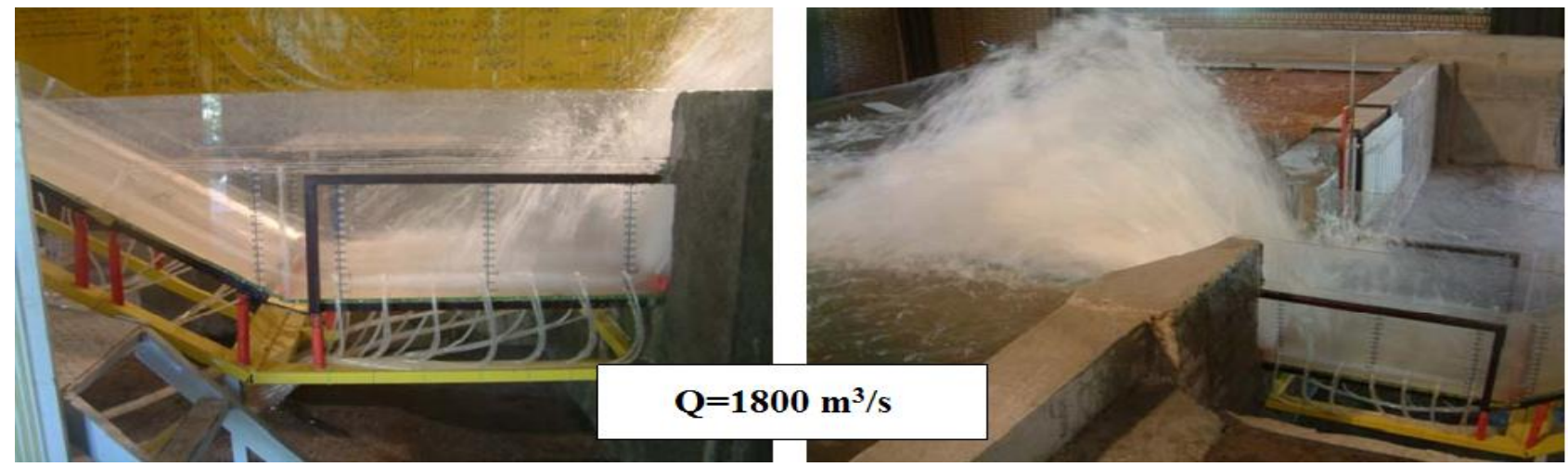

Figure 5. Formation of flow in the USBR II stilling basin with end adverse sloped for high discharge

So to remove this problem, dentate blocks were eliminated at the end stilling basin, and adverse slope surface at the end stilling basin was changed into a stepped surface (Figure 6). By implementing energy dissipater blocks at the end chute and 2, 3 and 4 steps at end of stilling basin, behavior and performance of flow were probed for discharging $830 \mathrm{~m}^{3} / \mathrm{s}$. Then the most optimal state of the stilling basin was selected. All of changes into structures of obstacles at the stilling basin are shown in Table 2.
Table 2. Inlet and outlet obstacles of the stilling basin

\begin{tabular}{c|c|c}
\hline $\begin{array}{c}\text { Number of } \\
\text { the Model }\end{array}$ & $\begin{array}{c}\text { Number of the } \\
\text { end obstacles }\end{array}$ & $\begin{array}{c}\text { Dimensions of } \\
\text { inlet obstacles }\end{array}$ \\
\hline 1 & 2 steps & $0.5 \mathrm{H}=0.75^{*} 0.5 * 0.5$ \\
\hline 2 & 3 steps & $0.5 \mathrm{H}=0.75^{*} 0.5 * 0.5$ \\
\hline 3 & 4 steps & $0.5 \mathrm{H}=0.75^{*} 0.5 * 0.5$ \\
\hline 4 & 2 steps & $1 \mathrm{H}=1.5 * 1 * 1$ \\
\hline 5 & 3 steps & $1 \mathrm{H}=1.5 * 1 * 1$ \\
\hline 6 & 4 steps & $1 \mathrm{H}=1.5 * 1 * 1$ \\
\hline 7 & 2 steps & $1.5 \mathrm{H}=3 * 1.5 * 1.5$ \\
\hline 8 & 3 steps & $1.5 \mathrm{H}=3 * 1.5 * 1.5$ \\
\hline 9 & 4 steps & $1.5 \mathrm{H}=3 * 1.5 * 1.5$ \\
\hline 10 & 2 steps & $2 \mathrm{H}=4 * 2 * 2$ \\
\hline 11 & 3 steps & $2 \mathrm{H}=4 * 2 * 2$ \\
\hline 12 & 4 steps & $2 \mathrm{H}=4 * 2 * 2$ \\
\hline
\end{tabular}




\subsubsection{Height of chute blocks}

The changes made into the inlet obstacles at USBR II stilling basin are as depicted in Figure 7.

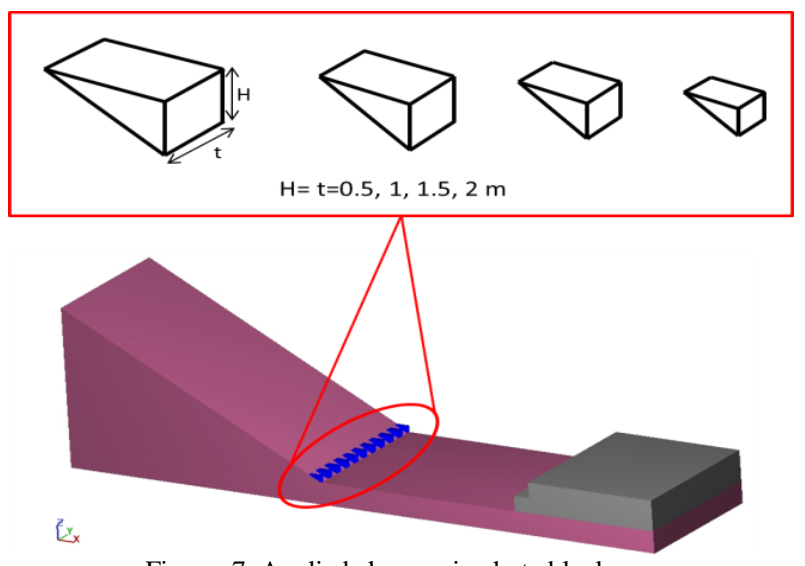

Figure 7. Applied changes in chute blocks

In Figure 8, the values of water height in length of USBR II stilling are illustrated for chute blocks with thickness and heights different for discharging $830 \mathrm{~m}^{3} / \mathrm{s}$. According to Figure 8 by considering the changes of water height for different states of chute blocks, it can be stated that the highest water

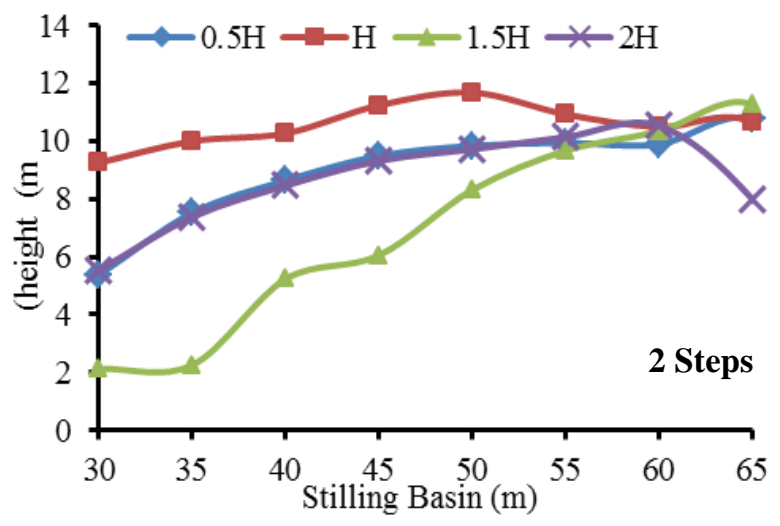

depth is related to obstacles with 1 and 1.5 equal to the standard height, and the least depth is related to the obstacles with height of 0.5 and 2 equal to standard height.

\subsubsection{Number of steps at the end stilling basin}

Figure 9, the water height is shown in stilling basin for 2, 3 and 4 steps at the end stilling basin for chute blocks with different height.

In Figure 9 according to the water height for different obstacles in the stilling basin, it can be concluded that when the height of chute blocks is $0.5 \mathrm{~m}$, flow characteristics are almost similar, and there are insignificant different between water heights. Also, the start of hydraulic jump is almost in similar place, but the initial depth of hydraulic jump for the stilling basin with 4 steps is a little more, and the flow has the same characteristics.

For chute blocks with height of $1 \mathrm{~m}$, by considering the same place of the start of hydraulic jump, the initial depth of hydraulic jump is higher for stilling basin with 2 steps, and conjugate depth in the stilling basin with 3 steps is almost 2.5 $m$ higher than other states.

For the chute blocks with height of $1.5 \mathrm{~m}$, the conjugate depth is same, but the initial depth for the stilling basin with 2 steps is about 3 to $5 \mathrm{~m}$ less than 2 other states. Furthermore, the difference between the initial and conjugate depths is about 10 $\mathrm{m}$.

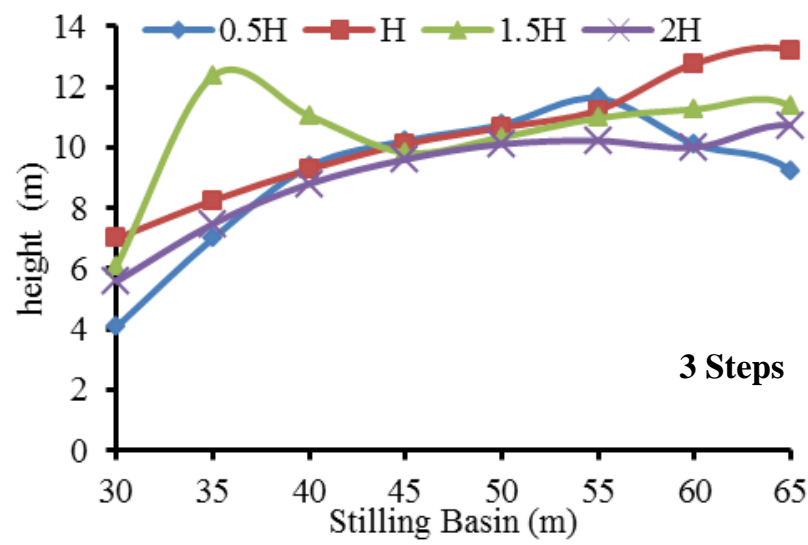

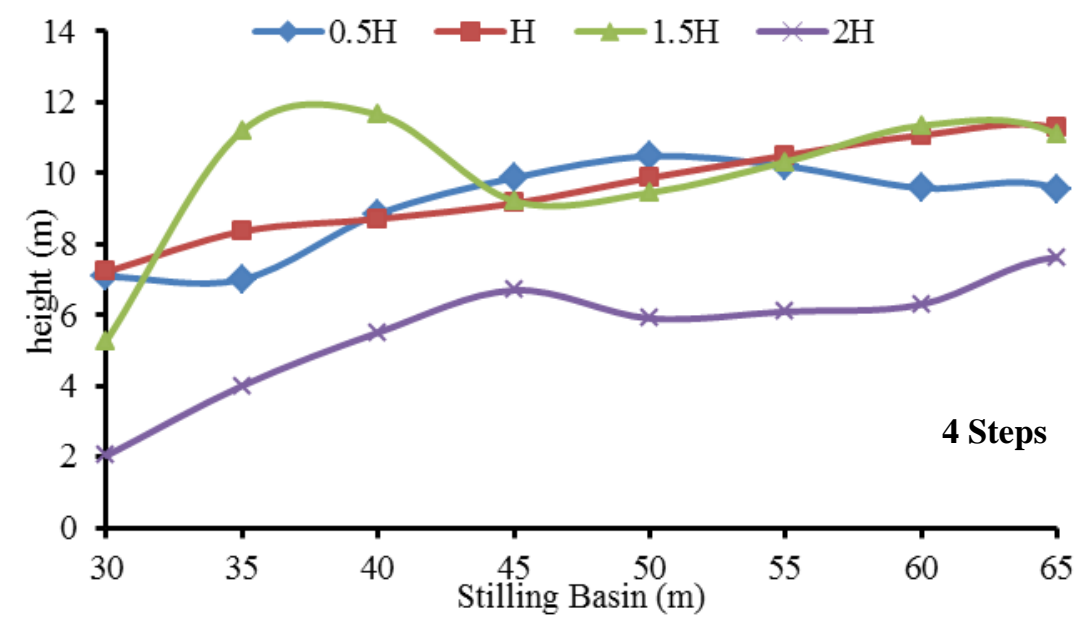

Figure 8. Water height for the different obstacles at the stilling basin 
When the height of chute blocks is $2 \mathrm{~m}$, the lowest water depth relates to the basin with 4 steps, and it is maximum value for the basin with 3 end steps. In general, it can be stated that in all conditions, the basin
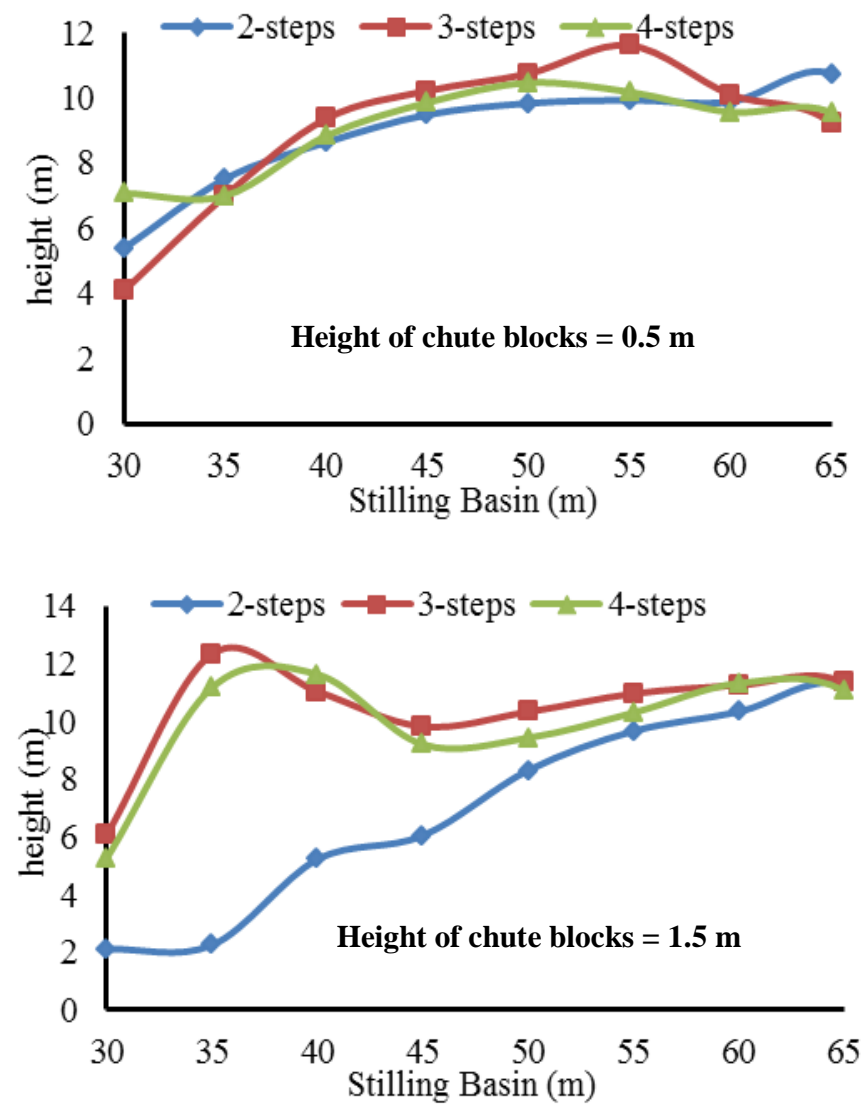

with 3 steps has higher relative depth in comparison with the other two states.
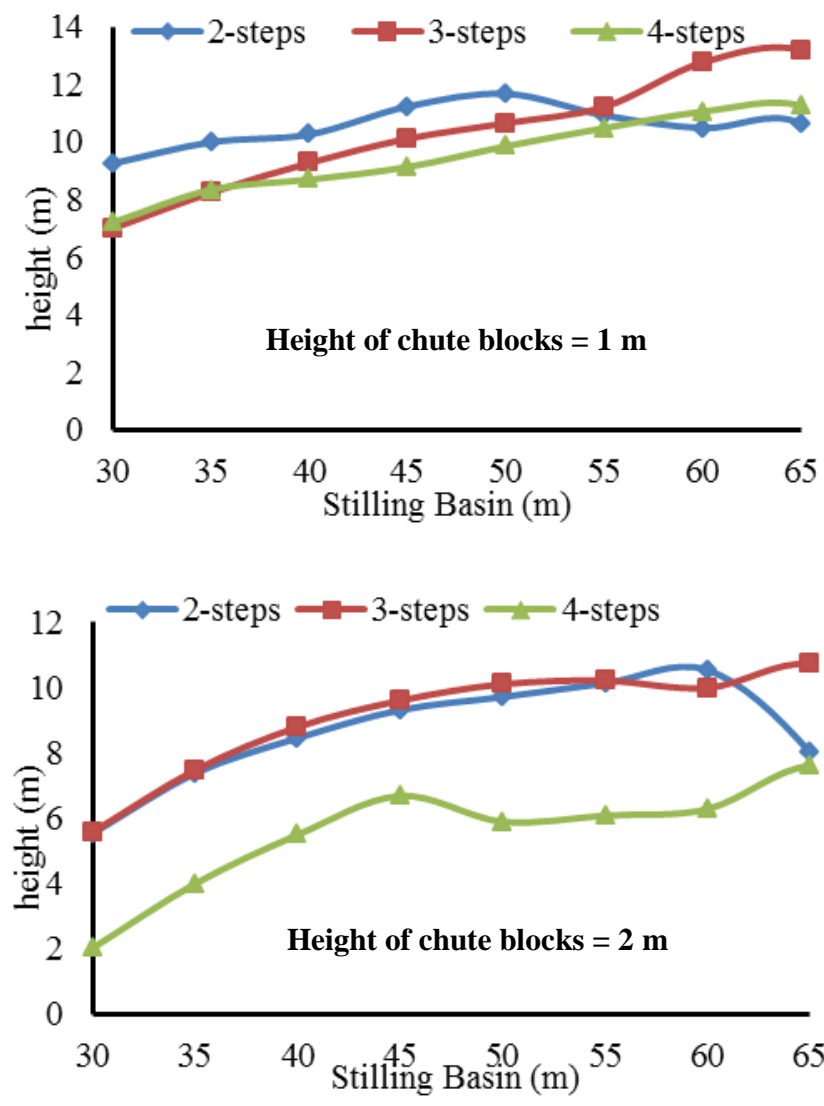

Figure 9. Water level changes in the stilling basin for different states

\subsection{Investigation of Parameters in Optimal Stilling Basin \\ 3.2.1 Pressure distribution}

Comparing experimental and numerical values of pressure in Figure 10 shows that $\mathrm{K}-\varepsilon$ turbulence model is more suitable estimator to static pressure rather than RNG turbulence model.

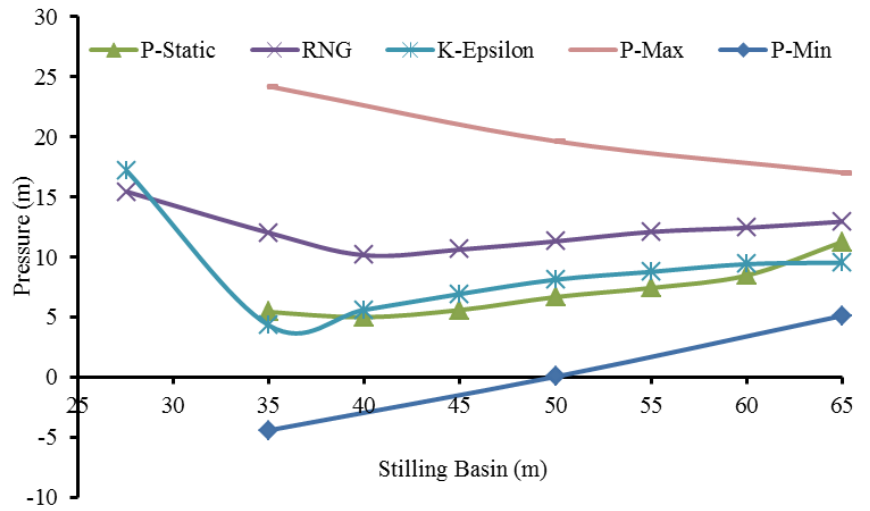

Figure 10. Pressure in the USBR II stilling basin with 3 steps
According to Figure 11, pressure is quite logically simulated by using $\mathrm{K}-\varepsilon$ turbulence model surrounding obstacles and middle of stilling basin so that the pressure surrounding obstacles is more than the middle of stilling basin due to encountering flow to obstacles.

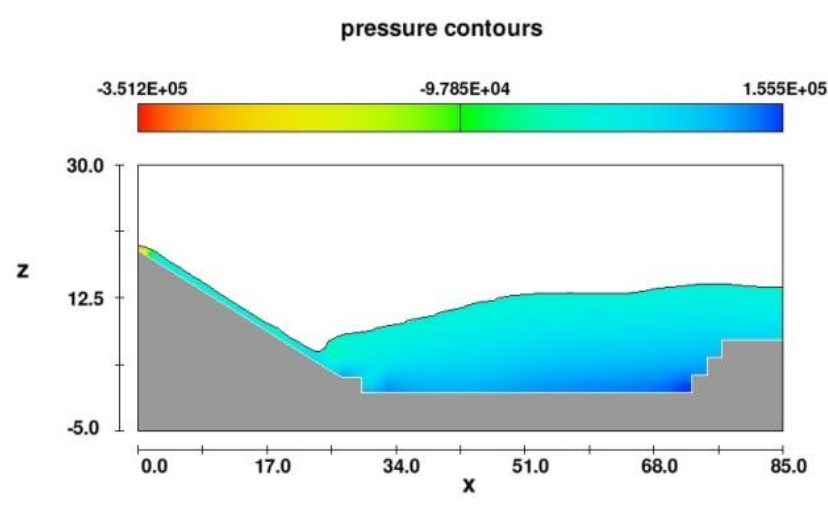

Figure 11.Pressure surrounding obstacles at stilling basin, K- $\mathcal{E}$ turbulence model 
Simulation of pressures in different parts of basin depicts that the pressure less follows than the hydrostatic distribution in start of the basin due to the pressure fluctuations. When the pressure approaches to the static pressure, the fluctuations are diminished, and pressure is approximately hydrostatic.

\subsubsection{Water Surface Profile in Optimal Stilling Basin}

Comparison of values of water surface profile along the stilling basin using K-E and RNG turbulence models in Figure 12 shows that numerical model has good agreement with the experimental data.


Figure 12. Water surface profile in the stilling basin

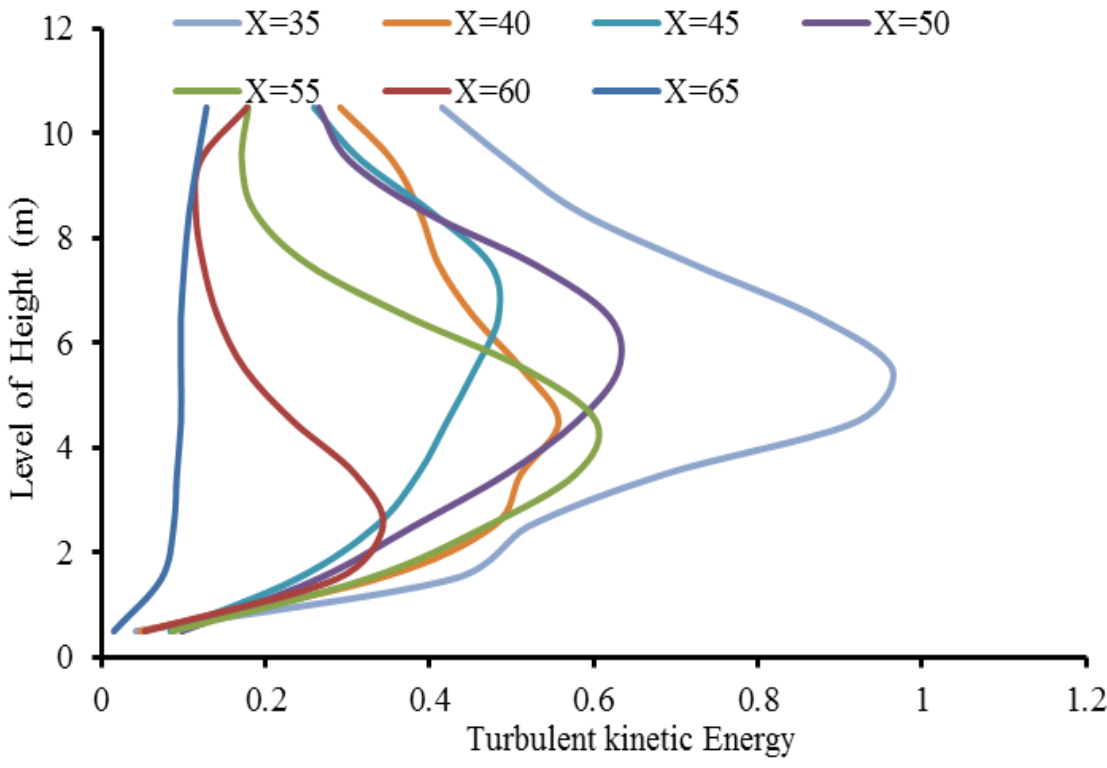




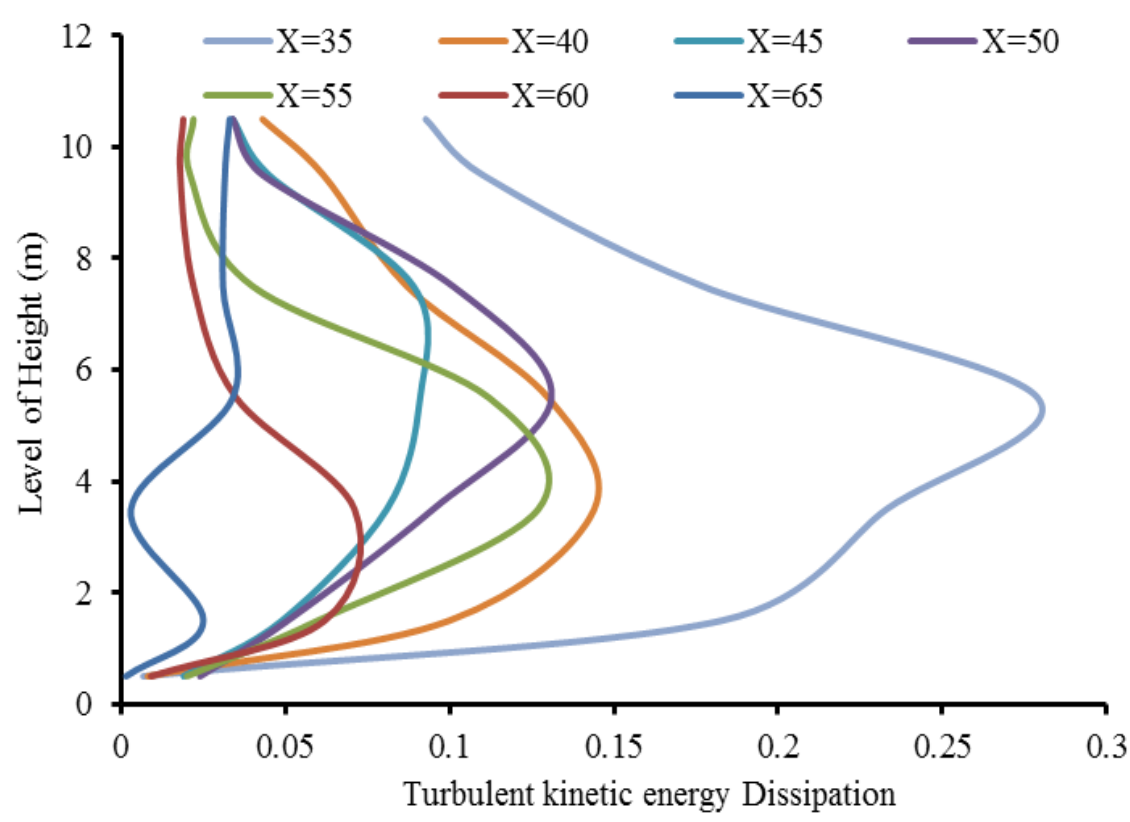

Figure 14. Turbulent kinetic energy and turbulent kinetic energy dissipation for different sections at stilling basin

\section{CONCLUSION}

In this study, the changes have been applied in the inlet and outlet obstacles of the USBR II stilling basin of Nazloochay dam modelIran for discharge more than design discharge. The aim of this study is optimal design of inlet and outlet obstacles at USBR II stilling basin. Results demonstrated that stilling basin with chute blocks with height of 1 and 1.5 equal to the standard state and 3 adverse steps at end was selected as the most optimal stilling basin. The Numerical modeling of pressure and water surface profiles in the most optimal stilling basin was done by using VOF method and K- $\varepsilon$ and RNG turbulence models. The results of numerical simulation showed that the numerical model has good agreement with the experimental model, as the numerical model can be used to analyze the flow in a stilling basin. Generally, it can be stated that numerical modeling is useful tool to calculate the non-measurable parameters in laboratory.

\section{REFERENCE}

[1] Abdelazim, M. A. and Yaser, A.M. 2010. Effect of stilling basin shape on the hydraulic characteristics of the flow downstream radial gates. Alexandria Engineering Journal, Vol. 49, pp. 393400.

[2] Armenio, V. Toscano, P. and Fioroto, V. 2000. On the Effects of a negative step on pressure fluctuations at the bottom of a hydraulic jump. Journal of Hydraulic Reaserch. Vol. 38, No. 5, pp. 359-368.

[3] Babaali, H.R. Shamsai, A. and Vosoughifar, H. 2015. Computational modeling of the hydraulic jump in the stilling basin with convergence walls using CFD codes. AJSE Journal of Science Engineering, AJSE, Vol. 40, No. 2, pp. 381-395.

[4] Bayon, A. Valero, D. García-Bartual, R. Valles-Moran, F. J. Jimenez. and P. Amparo, L. 2016. Performance assessment of OpenFOAM and Flow-3d in the numerical modeling of a low
Reynolds number hydraulic jump. Environmental Modeling \& Software, No. 80, pp. 322-335.

[5] Chanson, H. 2015. Energy Dissipation in Hydraulic Structures. IAHR Monographs, CRC Press/Balkema, Taylor \& Francis Group. ISBN: 978-1-138-02755-8.

[6] Chen, J. G. Zhang, J. M. Xu, W. L. and Wang, Y. R. 2010. Numerical simulation of the energy dissipation characteristics in stilling basin of multi-horizontal submerged jets. Journal of Hydrodynamics, Vol. 22, No. 5, pp. 732-741, DOI: 10.1016/s1001-6058(09)60110-4.

[7] Chow, V.T. 1959. Open Channel Hydraulics. McGraw-Hill Book Company, Inc, New York.

[8] Flow-3D user manual, Ver. 9.0.4.

[9] Forster, J.W. and Skrinde, R. A. 1950. Control of the hydraulic jump by sills. Transactions American Society Civil Engineering, ASCE, Vol. 115, No. 2415, pp. 988-991.

[10] Gamal, H. E. Abdelazim M. A. Neveen, B. A. and Ahmed, M. I. 2016. Effect of end step shape in the performance of stilling basins downstream radial gates. Journal of Scientific Research \& Reports, Vol. 9, No. 1, pp. 1-9, DOI: 10.9734/JSRR/2016/21452.

[11] Gehlot, B. K. and Tiwari, H.L. 2014. Critical review of stilling basin models for pipe outlet works. International Journal of Research in Engineering and Technology, eISSN: 2319-1163 | pISSN: 2321-7308.

[12] Hager, W. H. 1992. Energy Dissipaters and Hydraulic Jump. Water Science and Technology Library, Kluwer Academic Publishers. ISBN: 0-7923-1508-1.

[13] Hamedi, A., Ketabdar, M., Fesharaki, M., \& Mansoori, A. 2016. Nappe Flow Regime Energy Loss in Stepped Chutes Equipped with Reverse Inclined Steps: Experimental Development. Florida Civil Engineering Journal, 2:28-37.

[14] Hamedi, A., Hajigholizadeh, M., \& Mansoori, A. 2016. Flow Simulation and Energy Loss Estimation in the Nappe Flow 
Regime of Stepped Spillways with Inclined Steps and End Sill: A Numerical Approach. Civil Engineering Journal, 2(9), 426-437.

[15] Hamedi, A., Ketabdar, M. 2016. Energy Loss Estimation and Flow Simulation in the skimming flow Regime of Stepped Spillways with Inclined Steps and End Sill: A Numerical Model. International Journal of Science and Engineering Applications, 5(7), 399-407.

[16] Hamedi, A., Fuentes R. H., 2016. New Relationship between a Vertical Gate Opening and Downstream Flow Stability: Experimental Development. World Environ. Water Resour. Congr. 2016, pp. 47-57, 2016.

[17] Hamedi, A., Mansoori, A., Shamsai, A., \& Amirahmadian, S. 2014. The Effect of End Sill and Stepped Slope on Stepped Spillway Energy Dissipation. Journal of Water Sciences Research, $6: 1-15$.

[18] Hamedi, A., Malekmohammadi, I., Mansoori, A., \& Roshanaei, H. 2012. Energy Dissipation in Stepped Spillway Equipped with Inclined Steps Together with End Sill. In 2012 Fourth International Conference on Computational Intelligence and Communication Networks . IEEE.

[19] Hamedi, A., Mansoori, A., Malekmohamadi, I., \& Roshanaei, H. 2011. Estimating Energy Dissipation in Stepped Spillways with Reverse Inclined Steps and End Sill. In World Environmental and Water Resources Congress Reston, VA: American Society of Civil Engineers, Conference Proceeding :2528-2537.

[20] Harleman, D. R. F. 1955. Effect of baffle piers on stilling basin performance. Journal of Boston Society of Civil Engineers, Vol. 42, pp. 84-99.

[21] Hydraulic Model of Gutvand-Olia Dam, Report of Water Resources Institute in Iran. 2002. Project Code: HSM 8403.

[22] Hydraulic Model of Nazloochay dam, Report of Water Resources Institute in Iran, 2000. Project Code: HSM 8403.

[23] Moghaddam, A. K. (2017). Recent developments of ballastless tracks in high-speed and urban lines. International Journal of Research and Engineering, 4(4), 93-97.

[24] Moghaddam, A. K. A Review on the Current Methods of Railway Induced Vibration Attenuations. International Journal of Science and Engineering Applications, 6(4), 123-128.

[25] Ketabdar, M. 2016. Numerical and Empirical Studies on the Hydraulic Conditions of 90 degree converged Bend with Intake. International Journal of Science and Engineering Applications, 5(9), 441-444.

[26] Ketabdar, M. Hamedi, A. 2016 Intake Angle Optimization in 90degree Converged Bends in the Presence of Floating Wooden Debris: Experimental Development. Florida Civil Engineering Journal, 2, 22- 27.

[27] Mojtahedi, A. Nourani, V. Sori, N. and Sori, S. 2015. Computational Simulation of Flow and Energy Dissipation in Stepped Spillways. $10^{\text {th }}$ International Congress on Civil Engineering, University of Tabriz, Tabriz, Iran, 5-7 May.

[28] Morovati, K. Eghbalzadeh, A. and Soori, S. 2016. Numerical Study of Energy Dissipation of Pooled Stepped Spillways. Civil Engineering Journal. vol. 2, No. 5, pp. 208-220.

[29] Morovati, K., Eghbalzadeh, A., and Javan, M., 2016. Numerical investigation of the configuration of the pools on the flow pattern passing over pooled stepped spillway in skimming flow regime. Acta Mechanica, Vol. 227, No. 2. pp. 353-366. DOI 10.1007/s00707-015-1444-x.

[30] Mossa, M. Petrillo, M. and Chanson, H. 2003. Tail water level effects on flow conditions at an abrupt drop. Journal of Hydraulic Research, Vol. 41, No.1, pp. 39-51.

[31] Neveen, B. A. M. 2015. Effect of channel slope on hydraulic jump characteristics. Physical Science International Journal, Vol. 7, No. 4, pp. 223-233, DOI: 10.9734/PSIJ/2015/18527.

[32] Nik, Amirala Bakhshian, and Bahman Vahidi. "The effect of bone scaffold gradient architecture design on stem cell mechanical modulation: a computational study." Biomedical Engineering (ICBME), 2015 22nd Iranian Conference on. IEEE, 2015.

[33] Ohtsu, I., and Yasuda, Y. 1991. Transition from supercritical to subcritical flow at an abrupt drop. Journal of Hydraulic Research, Vol. 29, No. 1, pp. 309-328.

[34] Pagliara, S. and Palermo, M. 2015. Protected stilling basins downstream of low-head river training structures: energy dissipation. E-proc., $36^{\text {th }}$ World Congress, International Association Hydro-Environment Research, IAHR, The Hague, the Netherlands.

[35] Peterka, A.J. 1984. Hydraulic Design of Spillways and Energy Dissipaters. A water resources technical publication. Engineering. Monograph. 25.

[36] Shearin-Feimster, L.E. 2016. Impacts of tail water on the design of several stilling basins in the USA. $6^{\text {th }}$ International Symposium on Hydraulic Structures and Water System Management, DOI: 10.15142/T3260628160853.

[37] Tiwari, H.L. 2013. Design of Stilling Basin Model with Impact Wall and end Sill. Research Journal of Recent Sciences, Vol. 2, No. 3, pp. 59-63.

[38] Valero, D. Bung, D. and Matos, J. 2016. Numerical investigation of USBR type III stilling basin performance downstream of smooth and stepped spillways. $6^{\text {th }}$ International Symposium on Hydraulic Structures Portland, Oregon, USA, Hydraulic Structures and Water System Management, DOI:10.15142/T340628160853.

[39] Vischer, D.L. and Hager, W.H. 1998. Dam Hydraulics. Wiley Series in Water Resources Engineering.

[40] Wang, K. Sheng, J. and Gang, L. 2009. Numerical modeling of free-surface flows with bottom and surface-layer pressure treament[J]. Journal of Hydrodynamics, Vol. 21, No. 3, pp. 352359.

[41] WU, J.H. and AI, W.Zh. 2010. Flows through energy dissipaters with sudden reduction and sudden enlargement forms[J]. Journal of Hydrodynamics, Vol. 22, No. 3, pp. 360-365.

[42] Youngkyu, K., Gyewoon, Ch., Hyoseon, P., and Byeon, S. 2015. Hydraulic jump and energy dissipation with sluice gate. Water, No. 7, pp. 5115-5133; DOI:10.3390/w7095115.

[43] Zhao, Q. and Misra, S.K. 2004. Numerical study of a turbulent hydraulic jump. $17^{\text {th }}$ American Society Civil Engineering Mechanics Conference, University of Delaware, New York, DE. 